This is the peer reviewed version of the following article:

S. W. Ng, M. Krbal, R. Zazpe, J. Prikryl, J. Charvot, F. Dvořák, L. Strizik, S. Slang, H. Sopha, Y. Kosto, V. Matolin, F. K. Yam, F. Bures, J. M. Macak. (2017). MoSe $\mathrm{O}_{\mathrm{y}}$ - Coated 1D $\mathrm{TiO}_{2}$ Nanotube Layers: Efficient Interface for Light-Driven Applications. Adv. Mater. Interfaces. December, $1^{\text {st }}$. 1701146. https://doi.org/10.1002/admi.201701146

This article may be used for non-commercial purposes in accordance With Wiley-VCH Terms and Conditions for self-archiving". 


\section{ALD $\mathrm{Al}_{2} \mathrm{O}_{3}$ coatings significantly improve thermal,}

\section{chemical and mechanical stability of anodic $\mathrm{TiO}_{2}$}

\section{nanotube layers}

Raul Zazpe ${ }^{\dagger}$, Jan Prikryl ${ }^{\dagger}$, Viera Gärtnerovał, Katerina Nechvilova ${ }^{\S}$, Ludvik Benes ${ }^{\ddagger}$, Lukas Strizik ${ }^{\dagger}$, , Ales Jägerł, Markus Bosund ${ }^{\phi}$, Hanna Sopha ${ }^{\dagger}$ and Jan M. Macak ${ }^{\dagger}$,*

${ }^{\dagger}$ Center of Materials and Nanotechnologies, Faculty of Chemical Technology, University of Pardubice, nam. Cs. legii 565, 53002 Pardubice, Czech Republic.

‡ Laboratory of Nanostructures and Nanomaterials, Institute of Physics of the CAS, v.v.i., Na Slovance 2, 18221 Prague 8, Czech Republic

${ }^{\S}$ Institute of Chemistry and Technology of Macromolecular Materials, Faculty of Chemical Technology, University of Pardubice, Studentska 573, 53210 Pardubice, Czech Republic

${ }^{\ddagger}$ Joint laboratory of Solid-State Chemistry, Faculty of Chemical Technology, University of Pardubice, Studentska 95, 53210 Pardubice, Czech Republic

" Department of General and Inorganic Chemistry, Faculty of Chemical Technology, University of Pardubice, Studentska 573, 53210 Pardubice, Czech Republic

${ }^{\phi}$ Beneq, Olarinluoma 9, 02201 Espoo, Finland

* Corresponding Author: e-mail: jan.macak@upce.cz,Phone: +420-466 037401 
Keywords: $\mathrm{TiO}_{2}$, nanotubes, $\mathrm{Al}_{2} \mathrm{O}_{3}$ coating, $\mathrm{ALD}$, stability

In this work, we report on a very significant enhancement of the thermal, chemical and mechanical stability of self-organized $\mathrm{TiO}_{2}$ nanotubes layers, provided by thin $\mathrm{Al}_{2} \mathrm{O}_{3}$ coatings of different thicknesses prepared by atomic layer deposition (ALD). $\mathrm{TiO}_{2}$ nanotube layers coated with $\mathrm{Al}_{2} \mathrm{O}_{3}$ coatings exhibit significantly improved thermal stability as illustrated by the preservation of the nanotubular structure upon annealing treatment at high temperatures $\left(870{ }^{\circ} \mathrm{C}\right)$. In addition, a high anatase content is preserved in the nanotube layers, against expectation of the total rutile conversion at such a high temperature. Hardness of the resulting nanotube layers is investigated by nanoindentation measurements, and shows strongly improved values compared to uncoated counterparts. Finally, it is demonstrated that $\mathrm{Al}_{2} \mathrm{O}_{3}$ coatings guarantee unprecedented chemical stability of $\mathrm{TiO}_{2}$ nanotube layers in harsh environments of concentrated $\mathrm{H}_{3} \mathrm{PO}_{4}$ solutions. 
Introduction

Self-organized $\mathrm{TiO}_{2}$ nanotube layers have attracted remarkable attention within the past 15 years due their unique architecture, high surface area, semiconductive properties and biocompatibility. ${ }^{1,2}$ In addition, they are produced by a low-cost electrochemical anodization of Ti substrates in suitable electrolytes containing fluorides. All these features enabled utilization of $\mathrm{TiO}_{2}$ nanotube layers in a wide number of applications as photocatalyst, ${ }^{3,4}$ anode of dyesensitized solar cells (DSSC) ${ }^{5,6}$ and perovskite solar cells (PSC), ${ }^{7,8}$ gas sensors ${ }^{9}$ and biomedical materials, ${ }^{10,11}$ among others. In all these applications, $\mathrm{TiO}_{2}$ nanotube layers have shown superior performance compared to other $\mathrm{TiO}_{2}$ nanostructures. In parallel, important efforts have been carried out to tune the nanotube aspect-ratio ${ }^{12-14}$, and to improve the nanotube ordering ${ }^{15-17}$ and crystallinity ${ }^{18-20}$. Annealing treatment of amorphous as-synthesized $\mathrm{TiO}_{2}$ nanotube layers leads to their crystallization into anatase $\left(>280{ }^{\circ} \mathrm{C}\right)$, a combination of anatase and rutile $\left(>450{ }^{\circ} \mathrm{C}\right)$ or rutile $\left(>550{ }^{\circ} \mathrm{C}\right) .{ }^{18-20}$

The anatase nanotubular structure has shown to be more favorable than rutile for photoelectrochemically assisted applications, such as photocatalysis ${ }^{3,4}$ and DSSC. ${ }^{21,22}$ Thus, the stability of anatase nanotubular structure is highly desired, and numerous efforts have been focused on this target, especially at high temperatures. The introduction of alloying elements as $\mathrm{Nb}^{23}$ or $\mathrm{C}^{24}$ was reported to induce a shift of the anatase to rutile transition (further noted as ART) to higher temperature, and increased thermal resistance against collapse. However, the main disadvantage of alloying is the formation of undesired secondary impurity phases, e.g., Ti$\mathrm{Nb}_{2} \mathrm{O}_{5} \cdot{ }^{25}$ The ART threshold depends on whether the nanotube layers are attached or separated from the $\mathrm{Ti}$ substrate. High temperature stability (up to $700{ }^{\circ} \mathrm{C}$ ) of $\mathrm{TiO}_{2}$ nanotube arrays, preserving the nanotubular integrity and anatase structure, was reported for free-standing $\mathrm{TiO}_{2}$ 
nanotube arrays. ${ }^{26}$ For $\mathrm{TiO}_{2}$ nanotube layers attached to Ti substrate, anatase structure and no structural collapse was reported up to $800{ }^{\circ} \mathrm{C}$. The stability against collapse at this temperature is maintained either by a previous solvothermal treatment, ${ }^{27}$ or previous annealing at lower temperature. ${ }^{28}$ The highest published temperature without nanotube collapse $\left(\approx 1048{ }^{\circ} \mathrm{C}\right)$ was reached during flame annealing process. ${ }^{29}$ However, such flame high temperature processing led to undesired transition to rutile structure, and a significant uptake of carbon from the flame. Despite numerous efforts focused onto the high temperature stability of $\mathrm{TiO}_{2}$ nanotubes layer, the temperature working window is still restricted. Another constrain for applications of $\mathrm{TiO}_{2}$ nanotube layers is their limited chemical stability in harsh acidic environments, where nanotube layers undergo chemical dissolution.

The improvement of the thermal, chemical and eventually also mechanical properties of $\mathrm{TiO}_{2}$ nanotube layers would enable their utilization in previously non-imaginable working environments, and surely interesting expansion of their application range. In principle, addition of a thin continuous coating of an appropriate secondary material (with excellent thermal and chemical stability) within nanotubes should significantly alter also their stabilities. So far, however, no such treatment has been shown. To date, atomic layer deposition (ALD) technique is the only method that enables homogeneous, continuous and conformal coating of secondary materials into $\mathrm{TiO}_{2}$ nanotube layers. Deposition of $\mathrm{Al}_{2} \mathrm{O}_{3}{ }^{30-33}$ and $\mathrm{ZnO}^{34,35}$ coating by ALD into $\mathrm{TiO}_{2}$ nanotube layers have been reported yielding interesting synergic effects. The resulting composite heterostructures revealed significant improvement of their photovoltaic and photocatalytic performance due to enhanced charge separation induced by coatings of secondary materials. 
Therefore, in the present work we investigated the thermal, chemical and mechanical properties of self-organized $\mathrm{TiO}_{2}$ nanotube layers uniformly coated with $\mathrm{Al}_{2} \mathrm{O}_{3}$ layers of different nominal thicknesses: 1, 10 and $42 \mathrm{~nm}$. These coatings were carried out by atomic layer deposition (ALD) using different number of identical deposition cycles. After the $\mathrm{Al}_{2} \mathrm{O}_{3}$ coating, the $\mathrm{TiO}_{2}$ nanotube layers were annealed at temperature up to $870{ }^{\circ} \mathrm{C}$ for $1 \mathrm{~h}$ to evaluate their thermal stability. The resulting crystal structure and composition were analyzed through X-ray diffraction (XRD), scanning transmission electron microscopy (STEM). Mechanical properties (hardness) were characterized by nanoindentation measurements using atomic force microscope. The chemical stability was tested by soaking the $\mathrm{Al}_{2} \mathrm{O}_{3}$ coated $\mathrm{TiO}_{2}$ nanotube layers into $\mathrm{H}_{3} \mathrm{PO}_{4}$ solutions of different concentrations for $48 \mathrm{~h}$ at laboratory temperature and for additional 8 hours in solutions with temperature of $60^{\circ} \mathrm{C}$.

\section{Experimental Section}

Self-organized $\mathrm{TiO}_{2}$ nanotube layers with a thickness of $\approx 20 \mu \mathrm{m}$ and a nanotube diameter of $\approx 110 \mathrm{~nm}$ (aspect ratio $\approx 180$ ) were fabricated via anodization of Ti foils using previously published approach. ${ }^{36}$ Prior to anodization, the Ti foils (Sigma-Aldrich $0.127 \mathrm{~mm}$ thick, $99.7 \%$ purity) were degreased by sonication in isopropanol and acetone, then rinsed with isopropanol and dried in air. The electrochemical setup consisted of a 2 electrode configuration using a platinum foil as the counter electrode, while Ti foils (working electrodes) were pressed against an O-ring of the electrochemical cell, leaving $1 \mathrm{~cm}^{2}$ open to the electrolyte. A highvoltage potentiostat (PGU-200V, IPS Elektroniklabor GmbH) was employed to carry out the electrochemical experiments at room temperature. Ethylene glycol containing 1.5 vol.\% deionized water and $176 \mathrm{mM} \mathrm{NH}_{4} \mathrm{~F}$ was used as electrolyte. All electrolytes were prepared from 
reagent grade chemicals (Sigma Aldrich). Electrolytes were aged before the first use for $15 \mathrm{~h}$ by anodization of blank Ti foils at $60 \mathrm{~V}$ under the same conditions for the anodization experiments reasons for aging were described in the previous literature. ${ }^{37}$ Ti foils were anodized for $4 \mathrm{~h}$ after sweeping the potential from $0 \mathrm{~V}$ to $60 \mathrm{~V}$ with a sweeping rate of $1 \mathrm{~V} / \mathrm{s}$. After anodization the Ti foils were rinsed and sonicated in isopropanol and dried.

The $\mathrm{TiO}_{2}$ nanotube layers by were coated with $\mathrm{Al}_{2} \mathrm{O}_{3}$ by atomic layer deposition tool (thermal ALD, TFS 200, Beneq). This technique based on sequential and self-limiting gassurface reactions, allows conformal deposition of various coatings within $\mathrm{TiO}_{2}$ nanotube layers with a nanometer scale accurate thickness, as shown previously. ${ }^{36,38}$ Trimethylaluminum (TMA, Strem, elec. grade, 99.999+ \%) and deionized water (18 M 2$)$ were used as aluminum and oxygen precursors, respectively. Under these deposition conditions, one growth ALD cycle was defined by the following sequence: TMA pulse (1 s)- $\mathrm{N}_{2}$ purge (3 s)- $\mathrm{H}_{2} \mathrm{O}$ pulse (1 s)- $\mathrm{N}_{2}$ purge (3 s). All processes were carried out at a temperature of $200{ }^{\circ} \mathrm{C}$, and using $\mathrm{N}_{2}(99.9999 \%)$ as carrier gas at a flow rate of 400 standard cubic centimeters per minute (sccm). $\mathrm{Al}_{2} \mathrm{O}_{3}$ deposition was carried out running 8, 88 and 366 ALD cycles, leading to coatings of different nominal thicknesses: 1, 10 and $42 \mathrm{~nm}$, respectively. The number of cycles required for the different $\mathrm{Al}_{2} \mathrm{O}_{3}$ thicknesses was estimated from the growth per cycle value of the $\mathrm{Al}_{2} \mathrm{O}_{3}$ process at $200{ }^{\circ} \mathrm{C}$ $\left(\approx 1.1 \AA\right.$ /cycle). The thicknesses of $\mathrm{Al}_{2} \mathrm{O}_{3}$ coating were confirmed by variable angle spectroscopic ellipsometry (VASE® ellipsometer, J.A. Woollam, Co., Inc.) of $\mathrm{Al}_{2} \mathrm{O}_{3}$ coatings on Si wafers.

Upon the $\mathrm{Al}_{2} \mathrm{O}_{3}$ coating process, the $\mathrm{TiO}_{2}$ nanotube layers were annealed along with reference uncoated layers. The annealing process was carried out in a muffle oven in an air atmosphere applying a heating rate of $15{ }^{\circ} \mathrm{C} / \mathrm{min}$, until the target temperature $\left(870{ }^{\circ} \mathrm{C}\right)$ was 
reached. The annealing process proceeded at such temperature for $1 \mathrm{~h}$. Afterwards the layers were allowed to naturally cool down.

The morphology of the $\mathrm{TiO}_{2}$ nanotube layers was characterized by a field-emission SEM (FE-SEM JEOL JSM 7500F) and a scanning transmission electron microscope (STEM, FEI Tecnai F20 X-Twin) fitted with a high angle annular dark field (HAADF) detector and operating at $200 \mathrm{kV}$. The cross-sectional views were obtained from mechanically bent samples. Due to the rupture of the nanotube layers via this bending, it was possible to visualize nanotubes within the layers and coatings within nanotubes in various directions and nanotube layer depths. Dimensions of the nanotubes were measured and statistically evaluated using proprietary Nanomeasure software. Average values and standard deviations were calculated from at least 3 different locations with a high number of measurements $(\mathrm{n}>100)$.

Diffraction analyses of the $\mathrm{Al}_{2} \mathrm{O}_{3}$ coated $\mathrm{TiO}_{2}$ nanotube layers carried out using $\mathrm{X}$-ray diffractometer (XRD, D8 Advance, Bruker AXE) using Cu Ka radiation with secondary graphite monochromator and $\mathrm{Na}(\mathrm{Tl}) \mathrm{I}$ scintilation detector.

Nanoindentation measurements were performed to analyze the mechanical properties (hardness) of the $\mathrm{TiO}_{2}$ nanotube layers. They were determined by atomic force microscope (AFM, SOLVER NEXT, NT MDT) equipped with a nanoindentation head NS01NTF, and a Berkovich type of tip (three-sided pyramid geometry with a parameter of static stiffness, $\mathrm{k}=10.2$ $\pm 0.3 \mathrm{kN} / \mathrm{m}$ ). The nanotube layers were measured in longitudinal direction for compressive force of $0.5 \mathrm{mN}$, loaded for $100 \mathrm{~s}$. Fused silica $\mathrm{SiO}_{2}$ was used as a calibration sample (hardness, $\mathrm{H}=$ $9.5 \pm 0.5$ GPa by ISO 9450-76). The penetration depth of the tip was up to a maximum $10 \%$ of the total thickness of the nanotube layer The hardness was evaluated at $\sim 30$ different areas of each nanotube layer to ensure statistically relevant data set/significant results. 
The chemical stability of $\mathrm{Al}_{2} \mathrm{O}_{3}$ coated $\mathrm{TiO}_{2}$ nanotube layers was analyzed by soaking in $\mathrm{H}_{3} \mathrm{PO}_{4}$ solutions of different concentrations: 25, 50, 70 and 85 wt. \% (prepared from 85 wt. \% $\mathrm{H}_{3} \mathrm{PO}_{4}$, Penta). $\mathrm{TiO}_{2}$ nanotube layers were soaked in these solutions for $48 \mathrm{~h}$, including a thermal treatment for $8 \mathrm{~h}$ by which solutions were heated up at $60{ }^{\circ} \mathrm{C}$ to further study the nanotube chemical stability under warm acidic conditions. Before the subsequent SEM analysis, the layers were rinsed with water and dried in air.

Results and Discussion

\section{$\mathrm{Al}_{2} \mathrm{O}_{3}$ COATING OF $\mathrm{TiO}_{2}$ NANOTUBE LAYERS}

Highly ordered $\mathrm{TiO}_{2}$ nanotube layers, with a thickness of $\approx 20 \mu \mathrm{m}$ and an average diameter value of $\approx 110 \mathrm{~nm}$ (aspect ratio $\approx 180$ ), were prepared by anodization of Ti foils as described in detail in the experimental section. As-prepared amorphous $\mathrm{TiO}_{2}$ nanotube layers were coated with $\mathrm{Al}_{2} \mathrm{O}_{3}$ of different nominal thicknesses, namely 1,10 and $42 \mathrm{~nm}$ by ALD, as verified by SEM and ellipsometric measurements $(1.1 \pm 0.2,10 \pm 0.5$, and $44 \pm 2.1 \mathrm{~nm})$. Freshly coated nanotube layers were annealed at $870{ }^{\circ} \mathrm{C}$ for $1 \mathrm{~h}$ along with reference uncoated $\mathrm{TiO}_{2}$ nanotube layers. Figure 1 shows SEM images of the $\mathrm{TiO}_{2}$ nanotube layers with and without $\mathrm{Al}_{2} \mathrm{O}_{3}$ coating annealed at $870{ }^{\circ} \mathrm{C}$. Uncoated $\mathrm{TiO}_{2}$ nanotube layers (Figure 1a) collapsed during the annealing process into a pillar nanostructure (Figure 1b). When coated, the nanotube layers were preserved after the annealing process, regardless the thickness of the $\mathrm{Al}_{2} \mathrm{O}_{3}$, as apparent for coating of either $1 \mathrm{~nm}$ (Figure 1c-d), or $10 \mathrm{~nm}$ (Figure 1e-f). It is quite fascinating that even $1 \mathrm{~nm}$ thin $\mathrm{Al}_{2} \mathrm{O}_{3}$ coating can built a very thermally robust cage all over $\mathrm{TiO}_{2}$ nanotubes with some 20$40 \mathrm{~nm}$ thick tube walls. 
Figure 2 shows representative STEM-HAADF images of the nanotube body (separated from the annealed $\mathrm{Al}_{2} \mathrm{O}_{3}$ coated $(10 \mathrm{~nm}) \mathrm{TiO}_{2}$ nanotube layer by mechanical bending of the layers followed by sonication in methanol) at a low (a) and at a high magnification (b). Especially from Figure $2 \mathrm{~b}$, the interface between the $\mathrm{TiO}_{2}$ wall and $\mathrm{Al}_{2} \mathrm{O}_{3}$ coating is well distinguishable. There are actually two interfaces between the $\mathrm{TiO}_{2}$ wall and $\mathrm{Al}_{2} \mathrm{O}_{3}$ coating, as the $\mathrm{Al}_{2} \mathrm{O}_{3}$ coating is deposited inside (interior coating) and outside (exterior coating) the $\mathrm{TiO}_{2}$ tube walls. This feature is in accordance with our previous ALD work ${ }^{36}$, where we showed very good uniformity of $\mathrm{Al}_{2} \mathrm{O}_{3}$ coatings on the amorphous tubes and absence of any pinholes in the coating. As apparent from Figure 2, $\mathrm{Al}_{2} \mathrm{O}_{3}$ coatings remained continuous and pinhole-free even after annealing, during which thermally induced crystallization of $\mathrm{TiO}_{2}$ tube walls occurred. Some delamination of the coating seen at the outer and inner interface between $\mathrm{TiO}_{2}$ wall and $\mathrm{Al}_{2} \mathrm{O}_{3}$ coating (especially at Fig. 2b) stems most likely from the stress that these layers are exposed to during the preparation of specimens for SEM and STEM observation, which includes mechanical rupture of layers. These roughening and delamination events have no detrimental effect on coated nanotube layers that were not submitted for SEM and STEM and that completely survived soaking in $\mathrm{H}_{3} \mathrm{PO}_{4}$ solutions (described later in text).

\section{INFLUENCE OF THE COATING ON CRYSTAL STRUCTURE}

It is generally accepted that the annealing process influences crystal structure, phase transition and structural integrity of the $\mathrm{TiO}_{2}$ nanotube layers. ${ }^{18-20}$ It has also been accepted that amorphous as-prepared $\mathrm{TiO}_{2}$ nanotube layers crystallize into anatase above $280{ }^{\circ} \mathrm{C}$ in air. ${ }^{2}$ The anatase to rutile transition (ART) has been reported at different temperatures, most usually in the range of temperature between 500 and $600{ }^{\circ} \mathrm{C}$, depending on the nanotube dimensions (diameter, 
thickness, composition). Annealing at temperatures higher $\geq 600{ }^{\circ} \mathrm{C}$ leads to the coexistence of anatase and rutile structures, while total conversion to rutile structure takes place above $800{ }^{\circ} \mathrm{C} .39$

Figure 3a shows the XRD pattern obtained for reference uncoated $\mathrm{TiO}_{2}$ nanotube layers annealed for $1 \mathrm{~h}$ at either 400 or $870{ }^{\circ} \mathrm{C}$, respectively. In line with literature, the former exhibits pure anatase crystal phase identified by typical anatase peaks associated with planes (101), (004), (105), and (211), with a dominant orientation (101). The latter reveals pure rutile crystal phase with well-defined diffraction peaks of planes (110), (011), (111), (211), and (220). The intensity of the peak at $2 \theta=27.4^{\circ}$ indicates a preferred orientation along the (110) direction; no trace of anatase polymorphic phase is detected.

The XRD patterns, obtained from $\mathrm{Al}_{2} \mathrm{O}_{3}$ coated $\mathrm{TiO}_{2}$ nanotube layers annealed at $870{ }^{\circ} \mathrm{C}$ for $1 \mathrm{~h}$, are shown in Figure 3b. Therein the coexistence of anatase and rutile structures can be clearly seen, in contrast to the uncoated nanotube layers (Figure 3a) where rutile was exclusively formed at this temperature, in line with the previous work. ${ }^{18}$ The incomplete ART of coated $\mathrm{TiO}_{2}$ nanotube layers annealed at $870{ }^{\circ} \mathrm{C}$ stems from the hindered surface reconstruction of the $\mathrm{TiO}_{2}$ due to $\mathrm{Al}_{2} \mathrm{O}_{3}$ coating and also the impact of $\mathrm{Al}^{3+}$ as the phase transformation inhibitor. ${ }^{40} \mathrm{In}$ contrast, for uncoated nanotube layers (annealed at $870{ }^{\circ} \mathrm{C}$ ) the surfaces reconstruction can easily take place (no space constrains are present), allowing for the mass flow and rearrangements that yield complete rutile conversion, expected at this temperature. ${ }^{18}$ Another evidence for limited reconstruction of coated $\mathrm{TiO}_{2}$ nanotube layers annealed at $870{ }^{\circ} \mathrm{C}$ is the fact, that they do not collapse (sinter), which they would otherwise do without coating. In the case of thermally stable coated nanotube layers, the coating acts in similar fashion as it does for nanoparticles and nanorods that can be annealed, when coated, at high temperatures without undergoing sintering 
events. $^{41,42}$ Quantification of the content of each crystal phase and an average of the corresponding crystallite size are given in Table 1.

The anatase : rutile ratio was found to be dependent on the $\mathrm{Al}_{2} \mathrm{O}_{3}$ coating. The nanotube layer with the thickest $\mathrm{Al}_{2} \mathrm{O}_{3}$ coating (42 nm) exhibited dominant rutile structure $(62 \%)$ with peaks corresponding to the planes (110) (001) (111) (211) and (220), and only one minor anatase peak corresponding to (101) plane. In clear contrast, the anatase content for $10 \mathrm{~nm}$ and $1 \mathrm{~nm}$ thin $\mathrm{Al}_{2} \mathrm{O}_{3}$ coating was found to increase up to $73 \%$ and $83 \%$, respectively, on account of rutile. In addition, identical rutile peaks were revealed for them as for the nanotube layer with thickest $\mathrm{Al}_{2} \mathrm{O}_{3}$ coating (42 nm). It is noteworthy that the $1 \mathrm{~nm}$ thin $\mathrm{Al}_{2} \mathrm{O}_{3}$ coated nanotube layer revealed anatase peaks with preferential orientation along the (004) plane, instead of usual (101) plane. This feature was already reported by Acevedo et al., ${ }^{39}$ who associated a particular thermal stability of the nanotube layers to such anatase (004) plane. Based on the XRD results in Figure 3b, there is obvious retardation of the anatase to rutile transition (further noted as ART) with decreasing thickness of $\mathrm{Al}_{2} \mathrm{O}_{3}$ coatings (1 and $10 \mathrm{~nm}$ ).

In order to give a physical description of the results, factors affecting the ART need to be discussed. Firstly, we should consider the influence of the number of oxygen vacancies within the $\mathrm{TiO}_{2}$ on the ART temperature. Rath et al. ${ }^{43}$ reported that the larger is the number of oxygen vacancies within $\mathrm{TiO}_{2}$, the lower is its ART temperature, or the ART does not proceed at all and $\mathrm{TiO}_{2}$ remains in anatase form. The defects (in this case oxygen vacancies) provide a low energy mass transport route and lower such ART temperature. ${ }^{44}$ The number of oxygen vacancies within $\mathrm{TiO}_{2}$ is also strongly influenced by the annealing atmosphere. Previous works clearly indicated that dry annealing atmospheres such as $\mathrm{Ar}^{18}$ or $\mathrm{CO},{ }^{45}$ led to more oxygen vacancies in $\mathrm{TiO}_{2}$ than 
those performed in $\mathrm{O}_{2}$ or air. Thus, the ART was enhanced in oxygen-free atmospheres and resulted into larger rutile crystallites. ${ }^{18}$

Secondly it is important to define the fundamental reasoning behind the ART origin, which has been subject of controversy. Varghese et al. ${ }^{46}$ located the ART to proceed on the Ti substrate- $\mathrm{TiO}_{2}$ nanotube interface, where $\mathrm{Ti}$ metal would be directly thermally oxidized into rutile structure. The presence of oxygen vacancies in between the $\mathrm{Ti}$ substrate and $\mathrm{TiO}_{2}$ nanotube layer, was believed to induce the ART at such interface, spreading towards the whole nanotube walls in the course of time, as reported by Zhu et al. ${ }^{47}$ In contrast, Yu et al. ${ }^{48}$ proposed that ART does not stem from metal $\mathrm{Ti}$, but from the anatase (created at lower temperatures, while ramping up the temperature) at the interface between $\mathrm{TiO}_{2}$ nanotubes and $\mathrm{Ti}$ substrate, which converts to rutile at temperatures $\geq 600{ }^{\circ} \mathrm{C}$. In addition, works on annealing and crystallization of freestanding nanotube layers ${ }^{11,49}$ (i.e. nanotubes were detached from the $\mathrm{Ti}$ substrate before annealing) reported both the preservation of the anatase structure in the nanotube walls at temperatures higher than $600{ }^{\circ} \mathrm{C}$, and much higher triggering ART temperature. Those results would point on a significant role of metal $\mathrm{Ti}$ substrate- $\mathrm{TiO}_{2}$ nanotube interface on the ART.

There is a clear link between the experimental results obtained in this work, and the literature about factors affecting the ART. ${ }^{43,44}$ According to Figure 3, the anatase : rutile ratio is clearly dependent on the $\mathrm{Al}_{2} \mathrm{O}_{3}$ coating thickness. Assuming the results by Rath et al. ${ }^{43}$ that larger number of oxygen vacancies promotes the ART, it is clear that the $\mathrm{Al}_{2} \mathrm{O}_{3}$ coating within our $\mathrm{TiO}_{2}$ nanotube layers influences the number of oxygen vacancies as it possesses a barrier against the oxygen diffusion. ${ }^{50}$ For example, the thickest $\mathrm{Al}_{2} \mathrm{O}_{3}$ coating (42 nm) hinders the oxygen diffusion most significantly from all used coatings in this work, leads to highest number of oxygen vacancies within $\mathrm{TiO}_{2}$ nanotubes, and boosts the ART process that ends up with the 
highest rutile content. In contrast, the oxygen diffusion into $\mathrm{TiO}_{2}$ takes place more easily through thinner $\mathrm{Al}_{2} \mathrm{O}_{3}$ coatings (1 and $10 \mathrm{~nm}$ ), resulting in a lower number of oxygen vacancies, retarding the ART within $\mathrm{TiO}_{2}$ nanotubes. In addition, the largest rutile crystal size, calculated by Scherrer equation (Table 1), corresponds to the thickest $\mathrm{Al}_{2} \mathrm{O}_{3}$ coating, which also corroborates previously published findings on ART and size of rutile crystals. ${ }^{45,46}$

To get a complete picture about the ART, we also fully explored anatase $\mathrm{TiO}_{2}$ nanotube layers (annealed at $400{ }^{\circ} \mathrm{C}$ for $1 \mathrm{~h}$ ), shown in Figure 3a, for $\mathrm{Al}_{2} \mathrm{O}_{3}$ coating. We coated these nanotube layers with 1 and $10 \mathrm{~nm}$ of $\mathrm{Al}_{2} \mathrm{O}_{3}$ by $\mathrm{ALD}$, before undergoing a second thermal treatment at $870{ }^{\circ} \mathrm{C}$ for $1 \mathrm{~h}$. Firstly, the Figure 3c shows that the $\mathrm{Al}_{2} \mathrm{O}_{3}$ coated $(10 \mathrm{~nm}) \mathrm{TiO}_{2}$ nanotube layer consisted of $100 \%$ rutile, while in the $\mathrm{Al}_{2} \mathrm{O}_{3}$ coated $(1 \mathrm{~nm}) \mathrm{TiO}_{2}$ nanotube layer rutile content was only $26 \%$. These results confirm the active role of the $\mathrm{Al}_{2} \mathrm{O}_{3}$ coating for $\mathrm{TiO}_{2}$ crystal structure and are in line with the results and theories discussed in Figure 3b. Secondly, the significantly different crystal structure of the both investigated types of $\mathrm{Al}_{2} \mathrm{O}_{3}(10 \mathrm{~nm}) \mathrm{TiO}_{2}$ nanotube layer were revealed. The formerly annealed $\mathrm{Al}_{2} \mathrm{O}_{3}$ coated $(10 \mathrm{~nm}) \mathrm{TiO}_{2}$ nanotube layer (fully anatase comprised), underwent a complete ART and was $100 \%$ rutile comprised (see Figure 3c). In contrast, the initially amorphous $\mathrm{TiO}_{2}$ nanotube layer revealed a predominant anatase content of $\approx 74 \%$ (see Figure $3 \mathrm{~b}$ ). This comparison clearly confirms that the $\mathrm{TiO}_{2}$ structure influences the ART, and that it is clearly promoted for the $\mathrm{TiO}_{2}$ nanotube layers annealed to anatase before ART and ALD coating. In other words, the lack of coating induces during the thermal annealing to $400^{\circ} \mathrm{C}$ more oxygen vacancies in the $\mathrm{TiO}_{2}$ nanotube layers than it does when coatings are present during this annealing step. 


\section{MECHANICAL PROPERTIES}

The mechanical integrity of the $\mathrm{TiO}_{2}$ nanotube layers is of significant importance, especially for synthesis of devices based on flow-through membranes utilizing nanotube layers

opened on both sides. ${ }^{51}$ Even though some nanoindentation analyses of the $\mathrm{TiO}_{2}$ nanotube arrays were already carried out, ${ }^{52-59}$ nanotube layers modified with additional coatings, as in the present case, have not yet been analysed. Figure 4 shows hardness of $\mathrm{TiO}_{2}$ nanotube layers with $\mathrm{Al}_{2} \mathrm{O}_{3}$ coatings of different thicknesses as well as two reference nanotube layers. If not denoted otherwise, all nanotube layers were annealed at $870{ }^{\circ} \mathrm{C}$ for $1 \mathrm{~h}$ as the last processing step. The obtained hardness values show two prominent features. First, the uncoated amorphous (i.e., did not undergo annealing) $\mathrm{TiO}_{2}$ nanotube layer displayed lower hardness value than the annealed uncoated counterpart, fully rutile structure comprised. That was expected as the crystal structure has (as a rule of thumb) higher hardness than amorphous mass of the same compound. Second, the annealed $\mathrm{Al}_{2} \mathrm{O}_{3}$ coated $\mathrm{TiO}_{2}$ nanotube layers exhibited larger hardness with the increasing $\mathrm{Al}_{2} \mathrm{O}_{3}$ coating thickness. This can be ascribed to increasing content of rutile (Table 1 ) and to an increasing $\mathrm{Al}_{2} \mathrm{O}_{3}$ mass within the nanotubes.

Even tough rutile and anatase are similar in structure, the reason to rutile to be more mechanically robust than anatase is that its octahedra shares four edges instead four corners (anatase case) which leads to the formation of chains arranged subsequently in a four-fold arrange. ${ }^{57,59}$ This also explains why the $\mathrm{Al}_{2} \mathrm{O}_{3}$ coated $(1 \mathrm{~nm}) \mathrm{TiO}_{2}$ coated layer (which has mainly anatase structure as shown in Figure 3b) has lower hardness than uncoated annealed layers (completely rutile based, also shown in Figure 3a).

The hardness values presented here for high aspect ratio $(\approx 180)$ nanotube layers were larger than those found in literature, that reports typical hardness in the range from $94 \mathrm{MPa}$ to 
$\approx 3.5 \mathrm{GPa}^{52,54,57,58}$ However, it is difficult to establish a comparison, principally because the published reports show results for exclusively uncoated and lower aspect ratio $\mathrm{TiO}_{2}$ nanotubes layers with thicknesses from $\approx 625 \mathrm{~nm}$ to $8.5 \mu \mathrm{m}$ (compared to $20 \mu \mathrm{m}$ in the present case). Moreover, the use of different indenter tips (Vickers tips for microhardness, Berkovitch tips for nanohardness, cube corner tips for nanohardness, etc.) entails different hardness values. Nevertheless, it can be concluded that both the annealing treatment and the $\mathrm{Al}_{2} \mathrm{O}_{3}$ ALD coating resulted in a substantial enhancement of the mechanical properties of $\mathrm{TiO}_{2}$ nanotube layer.

\section{CHEMICAL STABILITY}

Finally, the chemical stability of $\mathrm{Al}_{2} \mathrm{O}_{3}$ coated $\mathrm{TiO}_{2}$ nanotube layers was investigated in strongly acidic environment, namely in $\mathrm{H}_{3} \mathrm{PO}_{4}$ solutions with different concentration. Such stability is significant for the nanotube layers to sustain in environments, where up to now they could not preserve their morphological integrity. For example in various biological environments with low $\mathrm{pH}$, the knowledge about the stability threshold is important. As it can be seen in Figure 5, even the thinnest coating $\left(1 \mathrm{~nm} \mathrm{Al}{ }_{2} \mathrm{O}_{3}\right)$ completely preserved the $\mathrm{TiO}_{2}$ nanotube layers from degradation in concentrated $\mathrm{H}_{3} \mathrm{PO}_{4}$. In line with that, no degradation was observed for any of the thicker $\mathrm{Al}_{2} \mathrm{O}_{3}$ coatings - 10 and $42 \mathrm{~nm}$ (data not shown here). The soaking tests were performed on the $40 \mathrm{~h}$ time scale for all nanotube layers. The $\mathrm{Al}_{2} \mathrm{O}_{3}$ coated ones survived without any change in $\mathrm{H}_{3} \mathrm{PO}_{4}$ of all used concentrations. This expands the already wide range of environments, where $\mathrm{ALD} \mathrm{Al}_{2} \mathrm{O}_{3}$ coatings are stable, in addition to published stability results of these coatings in various acidic $\left(\mathrm{H}_{2} \mathrm{SO}_{4}, \mathrm{HNO}_{3}, \mathrm{HCl}\right)$ and alkaline $(\mathrm{KOH})$ environments, ${ }^{60}$ and water. ${ }^{61}$ To make the $\mathrm{H}_{3} \mathrm{PO}_{4}$ environment even more harsh, the $\mathrm{H}_{3} \mathrm{PO}_{4}$ solutions were heated up to $60^{\circ} \mathrm{C}$ and soaking was carried out for additional $8 \mathrm{~h}$ (in total $48 \mathrm{~h}$ ). Since again no visible 
changes were observed, soaking experiments were terminated afterwards. Reference uncoated layers (namely as-anodized amorphous and annealed $\left(400^{\circ} \mathrm{C}\right.$ for $\left.1 \mathrm{~h}\right)$ nanotube layers) did not survive these conditions. In order to determine the chemical threshold conditions for these reference uncoated layers, lower $\mathrm{H}_{3} \mathrm{PO}_{4}$ concentrations had to be used. The stability threshold was revealed to be $10 \mathrm{wt}$ \% (Figure 5e) and 24 wt. \% (Figure 5f) on the scale of 24 hours for the amorphous and annealed case, respectively, without any heating. All in all, the results presented in Figure 5 for $\mathrm{Al}_{2} \mathrm{O}_{3}$ coated nanotube layers confirm the outstanding enhancement of the chemical stability of $\mathrm{TiO}_{2}$ nanotube layers provided by uniform $\mathrm{Al}_{2} \mathrm{O}_{3}$ coatings.

Thus, the present results, especially for the thinnest $\mathrm{Al}_{2} \mathrm{O}_{3}$ coating $(1 \mathrm{~nm})$, are very useful and promising for practical applications of the nanotube layers. As-treated $\mathrm{TiO}_{2}$ nanotube layers: i) maintain anatase structure (more favorable for photovoltaics and photocatalysis than rutile) in the tubes over a very broad temperature range, ii) possess significantly improved charge separation on the interface with various electrolytes (especially because electrons can tunnel to $\mathrm{TiO}_{2}$ via $\mathrm{Al}_{2} \mathrm{O}_{3}$ coatings thinner than $\approx 2 \mathrm{~nm}^{62}$ ), iii) possess strong mechanical integrity, and iv) provide extremely good stability in strongly acidic environments. All these features pave favorable way for the functionalization of $\mathrm{TiO}_{2}$ nanotube layers by secondary materials. It is foreseen that additional materials, such us various oxides, nitrides, sulfides, etc. may further expand the range of applications of $\mathrm{TiO}_{2}$ nanotube layers. Thermal and chemical stability of $\mathrm{Al}_{2} \mathrm{O}_{3}$ coated $\mathrm{TiO}_{2}$ nanotube layers can extend the utilization of nanotube layers for catalytic applications and sensing of gases (such as $\mathrm{CO}, \mathrm{NO}_{\mathrm{x}}, \mathrm{CH}_{3} \mathrm{CH}_{2} \mathrm{OH}, \mathrm{H}_{2}$, and $\mathrm{O}_{2}$ ) at high temperatures and/or in harsh acidic environment, so far unfeasible for uncoated $\mathrm{TiO}_{2}$ nanotube layers counterparts. In parallel, membranes composed of ultrahigh aspect ratio $\mathrm{TiO}_{2}$ nanotube layers that have been used for photocatalytic or flow-through experiments, ${ }^{51}$ may be prone to 
mechanical instabilities. Thus, they could greatly benefit from a thin $\mathrm{Al}_{2} \mathrm{O}_{3}$ coating to become mechanically more robust.

\section{Conclusions}

In this work, effects of $\mathrm{Al}_{2} \mathrm{O}_{3}$ coating produced by $\mathrm{ALD}$ on the crystal structure, mechanical and chemical properties of $\mathrm{TiO}_{2}$ nanotube layers were explored. Noteworthy improvement of the thermal stability upon annealing in air was revealed up to temperatures of $870{ }^{\circ} \mathrm{C}$, even with an extremely thin $\mathrm{Al}_{2} \mathrm{O}_{3}$ coating $(1 \mathrm{~nm})$. In contrast to uncoated $\mathrm{TiO}_{2}$ nanotube layers (100 vol. \% rutile), a high fraction of anatase structure (83 vol. \%) was determined for $\mathrm{Al}_{2} \mathrm{O}_{3}$ coated $(1 \mathrm{~nm}) \mathrm{TiO}_{2}$ nanotube layers upon annealing at $870{ }^{\circ} \mathrm{C}$, which is highly desired due to its optical and electronic properties for photovoltaic and photocatalytic applications. An enhanced hardness was revealed for $\mathrm{Al}_{2} \mathrm{O}_{3}$ coated $\mathrm{TiO}_{2}$ nanotube layers with a positive impact on the mechanical properties of nanotube layers. In addition, $\mathrm{Al}_{2} \mathrm{O}_{3}$ coatings provided to the $\mathrm{TiO}_{2}$ nanotube layers extremely good stability in extremely acidic environments of $\mathrm{H}_{3} \mathrm{PO}_{4}$ solutions with different concentrations. All in all, self-organized $\mathrm{TiO}_{2}$ nanotube layers coated with thin $\mathrm{Al}_{2} \mathrm{O}_{3}$ coatings yield superior thermal, chemical and mechanical stabilities that will extend their application range to previously non-imaginable working environments. 


\section{FIGURES}

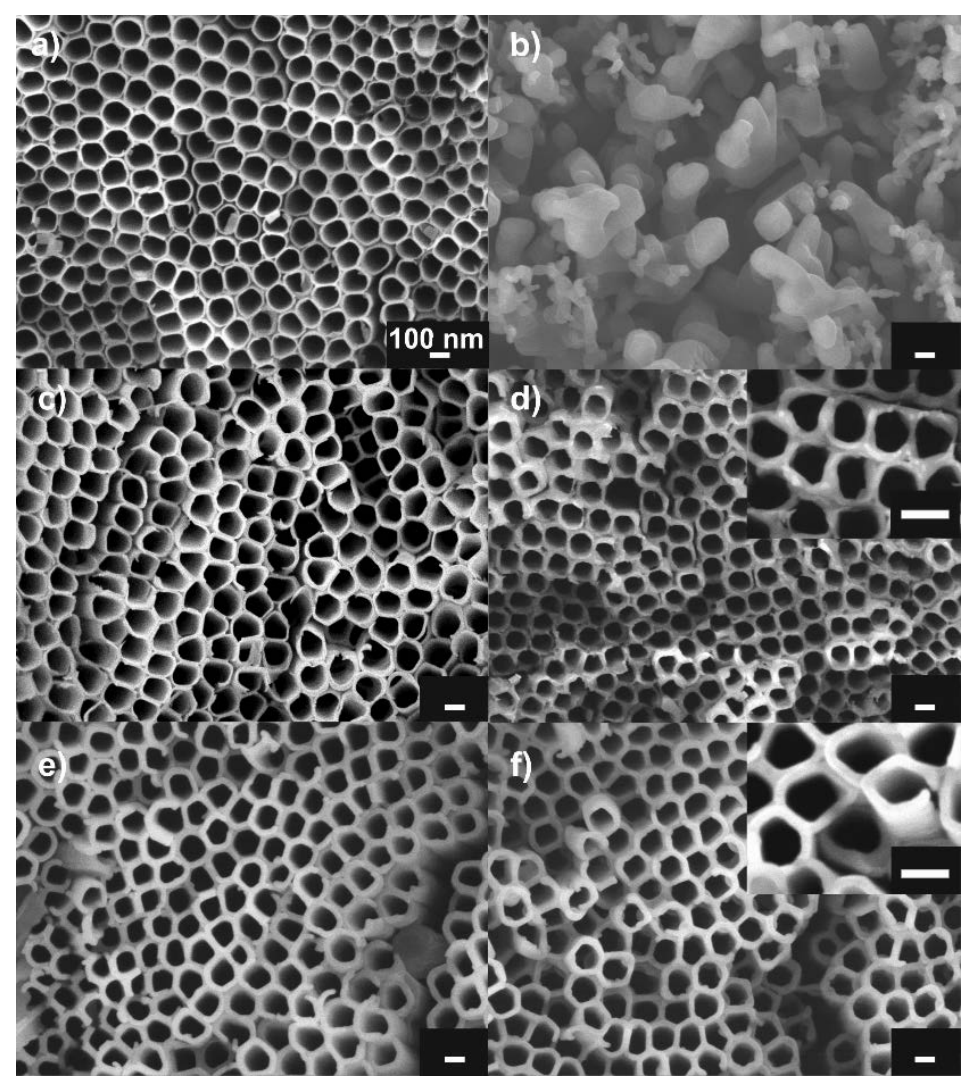

Figure 1. SEM top-view images of uncoated $\mathrm{TiO}_{2}$ nanotube layer (a) before and (b) after annealing; $\mathrm{Al}_{2} \mathrm{O}_{3}$ coated (1 nm) $\mathrm{TiO}_{2}$ nanotube layer (c) before and (d) after annealing; $\mathrm{Al}_{2} \mathrm{O}_{3}$ coated (10 nm) $\mathrm{TiO}_{2}$ nanotube layer (e) before and (f) after annealing. The annealing was carried out at $870{ }^{\circ} \mathrm{C}$ for $1 \mathrm{~h}$. Insets: magnification of the corresponding SEM images. All the scale bars denote $100 \mathrm{~nm}$. 


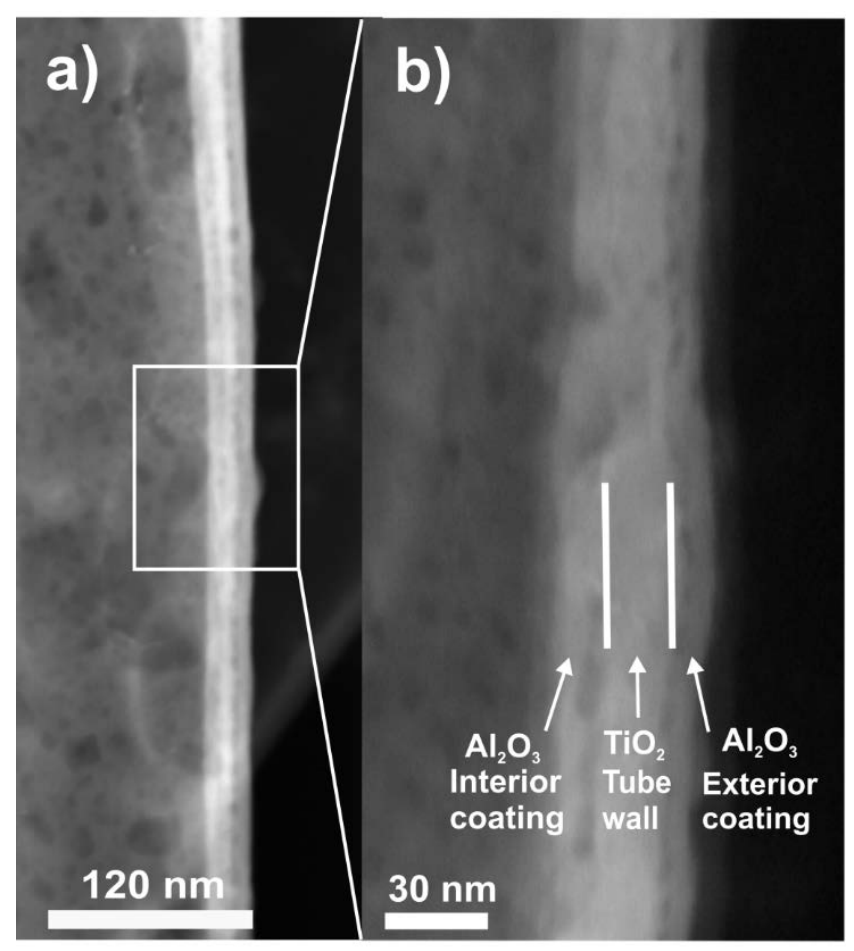

Figure 2. Representative STEM-HAADF images of (a) a fragment of $\mathrm{Al}_{2} \mathrm{O}_{3}$ coated (10 nm) $\mathrm{TiO}_{2}$ nanotube, and (b) the corresponding higher magnification of the nanotube wall. Interfaces between individual parts of the tubes are distinguished by solid lines, and appropriate description. 

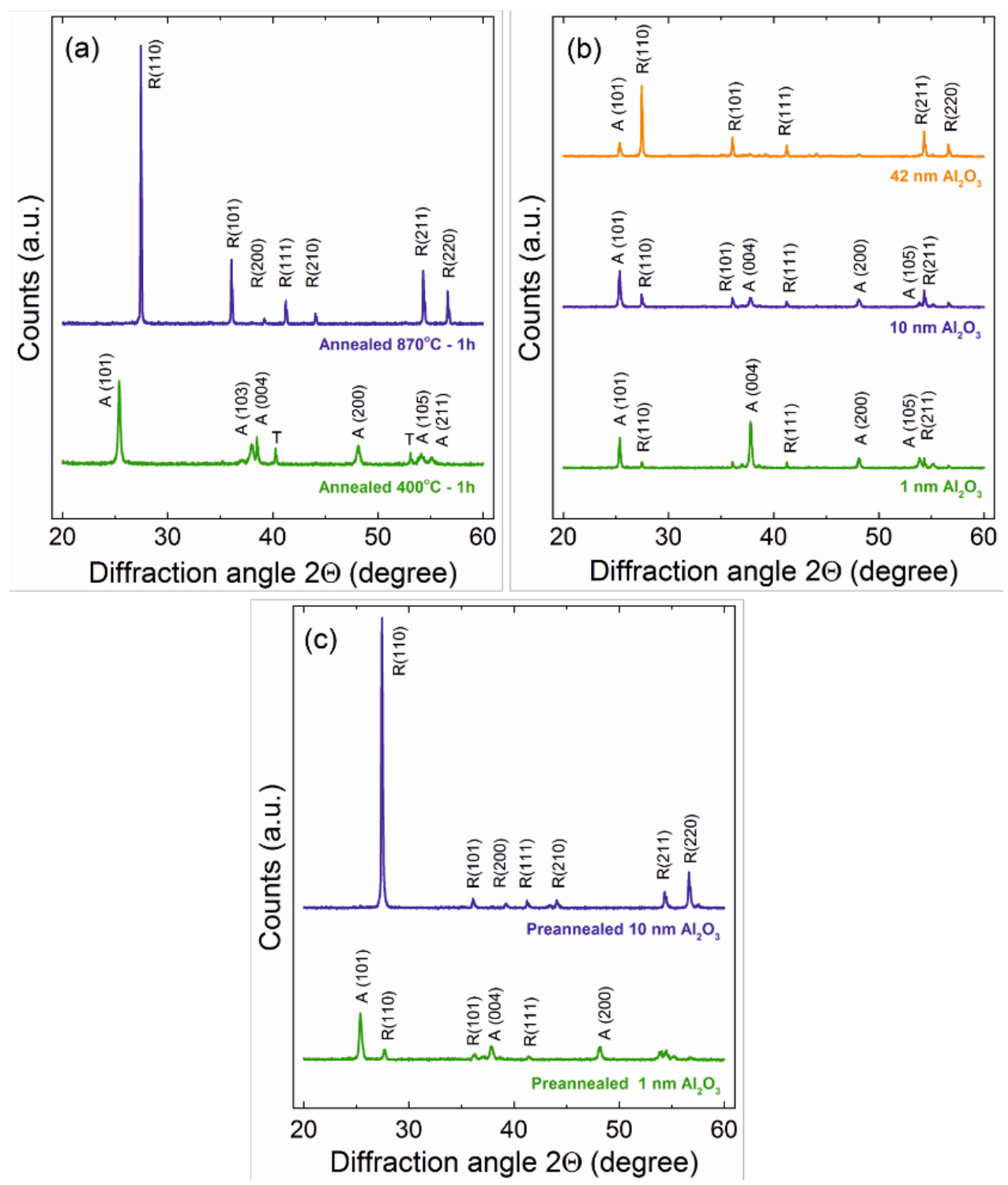

Figure 3. XRD patterns of a) uncoated $\mathrm{TiO}_{2}$ nanotube layers annealed at $870{ }^{\circ} \mathrm{C}$ and $400{ }^{\circ} \mathrm{C}$ for $1 \mathrm{~h}$; b) $\mathrm{Al}_{2} \mathrm{O}_{3}$ coated $\mathrm{TiO}_{2}$ nanotube layers with different coating thicknesses (1, 10 and $42 \mathrm{~nm}$ ) annealed at $870{ }^{\circ} \mathrm{C}$ for $1 \mathrm{~h}$; c) $\mathrm{Al}_{2} \mathrm{O}_{3}$ coated (1 and $10 \mathrm{~nm}$ ) $\mathrm{TiO}_{2}$ nanotube layers pre-annealed $\left(400{ }^{\circ} \mathrm{C}, 1 \mathrm{~h}\right)$ and second annealing at $870{ }^{\circ} \mathrm{C} . \mathrm{A}=$ anatase, $\mathrm{R}=$ rutile, $\mathrm{T}=$ titanium substrate. 


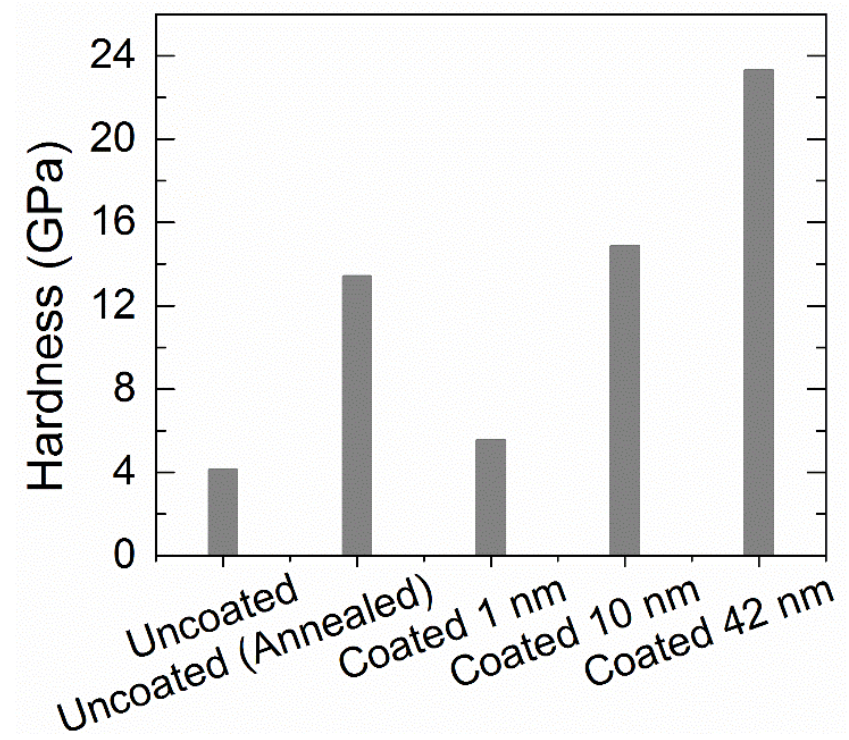

Figure 4. Hardness of different $\mathrm{TiO}_{2}$ nanotube layers determined by nanoindentation measurements. Except the sample marked “uncoated”, all nanotube layers were annealed at 870 ${ }^{\circ} \mathrm{C}$ for $1 \mathrm{~h}$. 


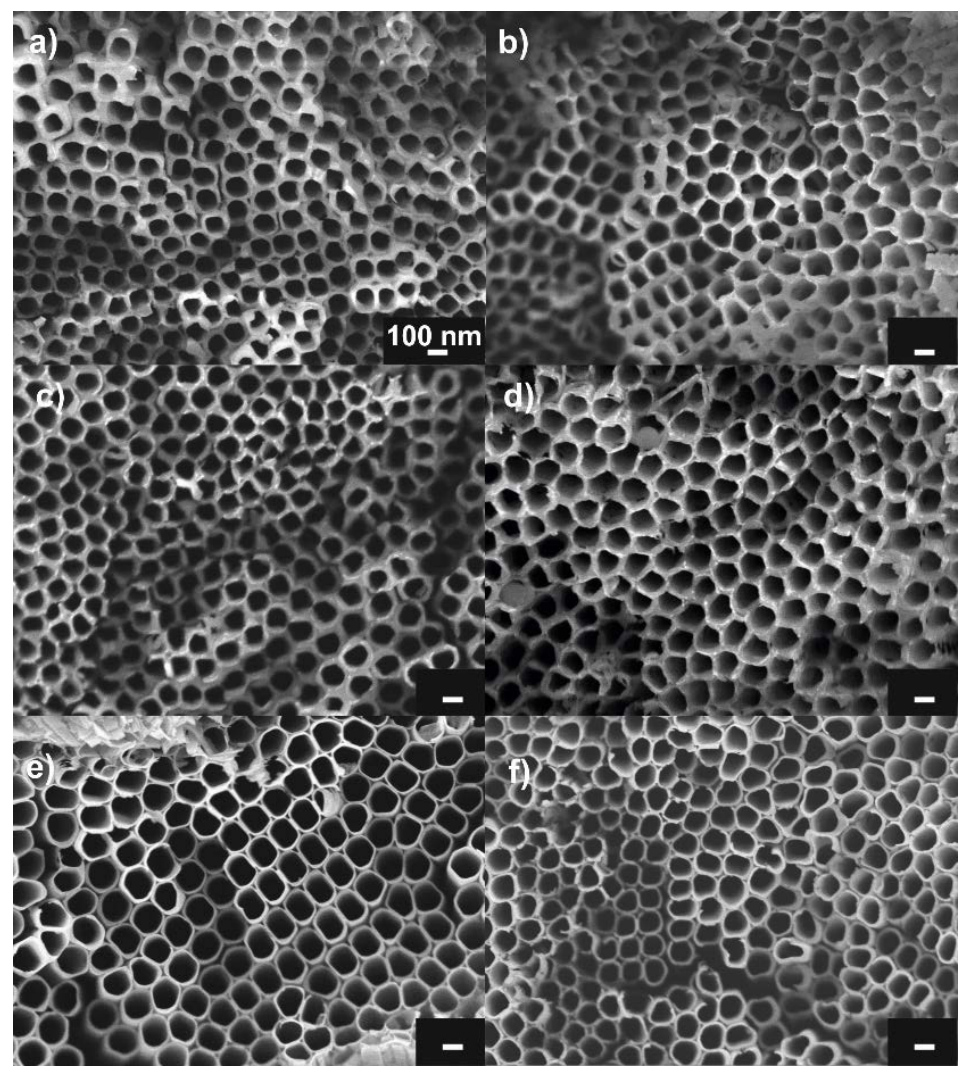

Figure 5. SEM top-view images of annealed $\mathrm{Al}_{2} \mathrm{O}_{3}$ coated (1nm) $\mathrm{TiO}_{2}$ nanotube layers before (a) and after soaking in $\mathrm{H}_{3} \mathrm{PO}_{4}$ solutions with different concentration: (b) 50 wt. \%, (c) 70 wt. \% and (d) 85 wt. \% in total for $48 \mathrm{~h}$ (last $8 \mathrm{~h}$ at $60{ }^{\circ} \mathrm{C}$ ). SEM top-view images of reference uncoated amorphous (e) and anatase (f) $\mathrm{TiO}_{2}$ nanotube layers after soaking in $\mathrm{H}_{3} \mathrm{PO}_{4}$ solutions of 10 and 40 wt. \%, respectively, for 24 h. All the scale bars denote $100 \mathrm{~nm}$. 


\section{TABLES}

Table 1. Percentage of anatase and rutile $\mathrm{TiO}_{2}$ crystal phase and the corresponding crystallite size, determined for the annealed and pre-annealed $\left(400{ }^{\circ} \mathrm{C}, 1 \mathrm{~h}\right) \mathrm{TiO}_{2}$ nanotube layers with different $\mathrm{Al}_{2} \mathrm{O}_{3}$ coating thicknesses after annealing at $870{ }^{\circ} \mathrm{C}$ for $1 \mathrm{~h}$.

\begin{tabular}{|ccccc|}
\hline $\begin{array}{c}\mathbf{A l}_{2} \mathbf{O}_{3} \text { coating } \\
\text { thickness (nm) }\end{array}$ & $\begin{array}{c}\text { Anatase } \\
\text { (vol.\%) }\end{array}$ & $\begin{array}{c}\text { Crystallite Size } \\
\text { (nm) }\end{array}$ & $\begin{array}{c}\text { Rutile } \\
\text { (vol.\%) }\end{array}$ & $\begin{array}{c}\text { Crystallite Size } \\
\text { (nm) }\end{array}$ \\
\hline $\mathbf{0}$ & 0 & - & 100 & 112.9 \\
\hline $\mathbf{1}$ & 83 & 78.4 & 17 & 93.5 \\
$\mathbf{1 0}$ & 73 & 52.3 & 27 & 81.5 \\
\hline $\mathbf{4 2}$ & 38 & 54.4 & 62 & 129.5 \\
\hline Pre-annealed 1 & 74 & 29.8 & 26 & 39.4 \\
\hline Pre-annealed 10 & 0 & - & 100 & 70.5 \\
\hline
\end{tabular}

\section{AUTHOR INFORMATION}

\section{Corresponding Author}

Jan M. Macak, E-mail: jan.macak@upce.cz

Notes

The authors declare no competing financial interest.

\section{ACKNOWLEDGMENT}

European Research Council and Ministry of Youth, Education and Sports of the Czech Republic are acknowledged for financial support of this work through projects 638857 and LM2015082, respectively. We thank Dr. Veronika Podzemná and Mr. Luděk Hromádko (University of Pardubice, Czech Republic) for SEM investigations. 


\section{REFERENCES}

(1) Macak, J. M.; Tsuchiya, H.; Ghicov, A.; Yasuda, K.; Hahn, R.; Bauer, S.; Schmuki, P. $\mathrm{TiO}_{2}$ nanotubes: Self-Organized Electrochemical Formation, Properties and Applications. Curr. Opin. Solid State Mater. Sci. 2007, 11, 3-18.

(2) Lee, K.; Mazare, A.; Schmuki, P. One-Dimensional Titanium Dioxide Nanomaterials: Nanotubes. Chem. Rev. 2014, 114, 9385-9454.

(3) Macak, J. M.; Zlamal, M.; Krysa, J.; Schmuki, P. Self-Organized $\mathrm{TiO}_{2}$ Nanotube Layers as Highly Efficient Photocatalysts, Small 2007, 3, 300-304.

(4) Liu, N.; Paramasivam, I.; Yang, M.; Schmuki, P. Some Critical Factors for Photocatalysis on Self-Organized $\mathrm{TiO}_{2}$ Nanotubes. J. Solid State Electrochem. 2012, 16, 3499-3504.

(5) Macak, J. M.; Tsuchiya, H.; Ghicov, A.; Schmuki, P. Dye-sensitized Anodic $\mathrm{TiO}_{2}$ Nanotubes. Electrochem. Commun. 2005, 7, 1133-1137.

(6) Mohammapour, F., Moradi, M.; Cha, G.; So, S.; Lee, K.; Altomare, M.; Schmuki, P. Comparison of Anodic $\mathrm{TiO}_{2}$-Nanotube Membranes used for Frontside-Illuminated DyeSensitized Solar Cells. ChemElectroChem. 2015, 2, 204-207.

(7) Gao, X.; Li, J.; Baker, J.; Hou, Y.; Guan, D.; Chen, J.; Yuan, C. Enhanced Photovoltaic Performance of Perovskite $\mathrm{CH}_{3} \mathrm{NH}_{3} \mathrm{PbI}_{3}$ Solar Cells with Freestanding $\mathrm{TiO}_{2}$ Nanotube Array Films. Chem. Commun. 2014, 50, 6368-6371.

(8) Salazar, R.; Altomare, M.; Lee, K.; Tripathy, J.; Kirchgeorg, R.; Nguyen, N. T.; Mokhtar, M.; Alshehri, A.; Al-Thabati, S. A.; Schmuki, P. Use of Anodic $\mathrm{TiO}_{2}$ Nanotube Layers as 
Mesoporous Scaffolds for Fabricating $\mathrm{CH}_{3} \mathrm{NH}_{3} \mathrm{PbI}_{3}$ Perovskite-based Solid-State Solar Cells. ChemElectroChem. 2015, 2, 824-828.

(9) Varghese, O. K.; Gong, D.; Paulose, M.; Ong, K. G.; Grimes, C. A. Hydrogen Sensing Using Titania Nanotubes. Sens. Actuators B 2003, 93, 338-344.

(10) Gulati, K.; Ramakrishnan, S.; Aw, M. S.; Atkins, G. J.; Findlay, D.M.; Losic, D. Biocompatible Polymer Coating of Titania Nanotube Arrays for Improved Drug Elution and Osteoblast Adhesion. Acta Biomater. 2012, 8, 449-456.

(11) Kulkarni, M,; Mazare, A,; Gongadze, E.; Perutkova, S,; Kralj-Iglic, V.; Milosev, I,; Schmuki, P.; Iglic, A.; Mozetic, M. Titanium Nanostructures for Biomedical Applications. Nanotechnology 2014, 26, 062002.

(12) Macak, J. M.; Tsuchiya, H.; Schmuki, P. High-Aspect-Ratio $\mathrm{TiO}_{2}$ Nanotubes by Anodization of Titanium. Angew. Chem. Int. Ed. 2005, 44, 2100-2102.

(13) Macak, J. M.; Tsuchiya, H.; Taveira, L.; Aldabergerova, S.; Schmuki, P. Smooth Anodic $\mathrm{TiO}_{2}$ Nanotubes. Angew. Chem. Int. Ed. 2005, 44, 7463-7465.

(14) Albu, S. P.; Ghicov, A.; Macak, J. M.; Schmuki, P. $250 \mu$ m Long Anodic $\mathrm{TiO}_{2}$ Nanotubes with Hexagonal Self-Ordering. Phys. Stat. Sol. (RRL) 2007, 1, R65-R67.

(15) Macak, J. M.; Albu, S.; Schmuki, P. Towards Ideal Hexagonal Self-Ordering of $\mathrm{TiO}_{2}$ Nanotubes. Phys. Stat. Sol. (RRL) 2007, 1, 181-183.

(16) Wang, D.; Yu, B.; Wang, C.; Zhou, F.; Liu, W. A Novel Protocol Toward Perfect Alignment of Anodized $\mathrm{TiO}_{2}$ Nanotubes. Adv. Mater. 2009, 21, 1964-1967. 
(17) Sopha, H.; Jäger, A.; Knotek, P.; Tesar, K.; Jarosova, M.; Macak, J. M. Self-Organized Anodic $\mathrm{TiO}_{2}$ Nanotube Layers: Influence of the $\mathrm{Ti}$ substrate on Nanotube Growth and Dimensions. Electrochim. Acta, 2016, 190, 744-752.

(18) Ghicov, A.; Tsuchiya, H.; Macak, J. M.; Schmuki, P. Annealing Effects on the Photoresponse of $\mathrm{TiO}_{2}$ Nanotubes. Phys. Stat. Sol. (RRL) 2006, 203, R28-R30.

(19) Albu, S. P.; Ghicov, A.; Aldabergenova, S.; Drechsel, P.; LeClere, D.; Thomson, G. E.; Macak, J. M.; Schmuki, P. Formation of Double-Walled $\mathrm{TiO}_{2}$ Nanotubes and Robust Anatase Membranes. Adv. Mater. 2008, 20, 4135-4139.

(20) Macak, J. M.; Aldabergerova, S.; Ghicov, A.; Schmuki, P. Smooth Anodic $\mathrm{TiO}_{2}$ Nanotubes: Annealing and Structure. Phys. Status Solidi A 2006, 203, R67-R69.

(21) Mohammadpour, F.; Moradi, M.; Lee, K.; Gha, G.; So, S.; Kahnt, A.; Guldi, D.M.; Altomare, M.; Schmuki, P. Enhanced Performance of Dye-Sensitized Solar Cells on $\mathrm{TiO}_{2}$ Nanotube Membranes Using an Optimized Annealing Profile. Chem. Commun. 2015, 51, 16311634.

(22) Mirabolghasemi, H.; Liu, N.; Lee, K.; Schmuki, P. Formation of 'Single Walled' $\mathrm{TiO}_{2}$ Nanotubes with Significantly Enhanced Electronic Properties for Higher Efficiency Dye Sensitized Solar Cells. Chem. Commun. 2013, 49, 2067-2069.

(23) Arbiol, J.; Cerda, J.; Dezanneau, G.; Cicera, A.; Peiro, F.; Cornet, A.; Morante, J. R. Effects of Nb Doping on the $\mathrm{TiO}_{2}$ Anatase-to-Rutile Phase Transition. J Appl Phys. 2002, 92, 853-861. 
(24) Tryba, B.; Moravski, A. W.; Inagaki, M. A New Route for Preparation of $\mathrm{TiO}_{2}-\mathrm{Mounted}$ Activated Carbon. Appl Catal B: Environ. 2003, 46, 203-208.

(25) Ghicov, A.; Aldabergerova, S.; Tsuchiya, H.; Schmuki, P. $\mathrm{TiO}_{2}-\mathrm{Nb}_{2} \mathrm{O}_{5}$ Nanotubes with Electrochemically Tunable Morphologies. Angew Chem Int Ed. 2006, 45, 6993-6996.

(26) Lin, J.; Guo, M.; Yip, C. T.; Lu, W.; Zhang, G.; Liu, X.; Zhou, L.; Chen, X.; Huang. H. High Temperature Crystallization of Free-Standing Anatase $\mathrm{TiO}_{2}$ Nanotube Membranes for High Efficiency Dye-Sensitized Solar Cells. Adv. Funct. Mater. 2013, 23, 5952-5960.

(27) Rao, B. M.; Roy, S. C. Anatase $\mathrm{TiO}_{2}$ Nanotube Arrays with High Temperature Stability. RSC Adv. 2014, 4, 38133-38139.

(28) Mohammadpour, F.; Altomare, M.; So, S.; Lee, K.; Mokhtar, M.; Alshehri, A.; AlThabaiti, S. A.; Schmuki, P. High-Temperature Annealing of $\mathrm{TiO}_{2}$ Nanotube Membranes for Efficient Dye-Sentitized Solar Cells. Semicond. Sci. Technol. 2016, 31, 014010 (8pp).

(29) Mazare, A.; Paramasivam, I.; Schmidt-Stein, F.; Lee, K.; Demetrescu, I.; Schmuki, P. Flame Annealing Effects on Self-Organized $\mathrm{TiO}_{2}$ Nanotubes. Electrochim. Acta 2012, 66, 12-21.

(30) Gao, X.; Guan, D.; Huo, J.; Chen, J.; Yuan, C. Free Standing $\mathrm{TiO}_{2}$ Nanotube Array Electrodes with an Ultra-Thin $\mathrm{Al}_{2} \mathrm{O}_{3}$ Barrier Layer and $\mathrm{TiCl}_{4}$ Surface Modification for Highly Efficient Dye Sensitized Solar Cells. Nanoscale 2013, 5 (21), 10438-10446.

(31) Jae-Yup, K.; Kyeong-Hwan, L.; Junyoung, S.; Sun Ha, P.; Jin Soo, K.; Kyu Seok, H.; Myung Mo, S.; Nicola, P.; Yung-Eun, S. Highly Ordered and Vertically Oriented $\mathrm{TiO}_{2} / \mathrm{Al}_{2} \mathrm{O}_{3}$ Nanotube Electrodes for Application in Dye-Sensitized Solar Cells. Nanotechnology 2014, 25 (50), 504003. 
(32) Gui, Q.; Zhen, X.; Zhang, H.; Cheng, C.; Zhu, X.; Yin, M.; Song, Y.; Lu, L.; Chen, X.; Li, D. Enhanced Photoelectrochemical Water Splitting Performance of Anodic $\mathrm{TiO}_{2}$ Nanotube Arrays by Surface Passivation. ACS Appl. Mater. Interfaces 2014, 6, 17053-17058.

(33) Zeng, M.; Peng, X.; Liao, J.; Wang, G.; Li, Y.; Li, J.; Qin, Y.; Wilson, J.; Song, A.; Lin, S. Enhanced Photoelectrochemical Performance of Quantum Dot-Sensitized $\mathrm{TiO}_{2}$ Nanotube Arrays with $\mathrm{Al}_{2} \mathrm{O}_{3}$ Overcoating by Atomic Layer Deposition. Phys. Chem. Chem. Phys. 2016, $18,17404-17413$.

(34) Cai, H.; You, Q.; Hu, Z.; Duan, Z.;, Cui, Y.; Sun, J.; Xu, N.; Wu, J. Fabrication and Correlation between Photoluminescenceand Photoelectrochemical Properties of Vertically Aligned $\mathrm{ZnO}$ coated $\mathrm{TiO}_{2}$ Nanotube Arrays. Solar Energy Materials\&Solar Cells 2014, 123, 233-238.

(35) Jeong, J.-S.; Choe, B.-H.; Lee, J.-H.; Lee, J.-J.; Choi, W.-Y. ZnO-Coated $\mathrm{TiO}_{2}$ Nanotube Arrays for a Photoelectrode in Dye-Sensitized Solar Cells. J. Electron. Mater. 2014, 43, 375380.

(36) Zazpe, R.; Knaut, M.; Sopha, H.; Hromadko, L.; Albert, M.; Prikryl, J.; Gärtnerová, V.; Bartha, J. W.; Macak, J. M. Atomic Layer Deposition for Coating of High Aspect Ratio $\mathrm{TiO}_{2}$ Nanotube Layers. Langmuir 2016, 32, 10551-10558.

(37) Sopha, H.; Hromadko, L.; Nechvilova, K.; Macak, J. M. Effect of Electrolyte Age and Potential Changes on the Morphology of $\mathrm{TiO}_{2}$ Nanotubes. Journal of Electroanalytical Chemistry 2015, 759, 122-128. 
(38) Macak, J. M.; Prikryl, J.; Sopha, H.; Strizik, L. Antireflection $\ln _{2} \mathrm{O}_{3}$ Coatings of SelfOrganized $\mathrm{TiO}_{2}$ Nanotube Layers Prepared by Atomic Layer Deposition. Phys. Status Solidi RRL 2015, 9, 516-520.

(39) Acevedo-Peña, P.; Carrera-Crespo, J. E.; Gonzalez, F.; Gonzalez, I. Effect of Heat Treatment on the Crystal Phase Composition, Semiconducting Properties and Photoelectrocatalytic Color Removal Efficiency of $\mathrm{TiO}_{2}$ Nanotubes Arrays. Electrochimica Acta 2010, $140,564-571$.

(40) Hanaor, D. A. H.; Sorrell, C. C. Review of the Anatase to the Rutile Phase Transformation. J. Mater. Sci. 2011, 46, 855-874.

(41) Lu, J.; Fu, B.; Kung, M. C.; Xiao, G.; Elam, J. W.; Kung, H. H.; Stair, P. C. Coking-and Sintering-Resistant Palladium Catalyst Achieved Through Atomic Layer Deposition. Science 2012, 335, 1205-1208.

(42) Ma, L.; Huang, Y.; Hou, M.; Xie, Z.; Zhang, Z. Silver Nanorods Wrapped with Ultrathin $\mathrm{Al}_{2} \mathrm{O}_{3}$ Layers Exhibiting Excellent SERS Sensitivity and Outstanding SERS Stability. Scientific Reports 2015, 5, 12890.

(43) Rath, C.; Mohanty, P.; Pandey, A. C.; Mishra, N. C. Oxygen Vacancy Induced Structural Phase Transformation in $\mathrm{TiO}_{2}$ Nanoparticles. J. Phys. D: Appl. Phys. 2009, 42, 205101.

(44) Reidy, D. J.; Holmes, J. D.; Morris, M. A. The Critical Size Mechanism for the Anatase to Rutile Transformation in $\mathrm{TiO}_{2}$ and Doped-TiO 2 . J. Eur. Ceram.Soc. 2006, 6, 1527-1534. 
(45) Zhang, Y. H.; Xiao, P.; Zhou, X.Y.; Liu, D.W.; Garcia, B.B.; Cao, G.Z. Carbon Monoxide Annealed $\mathrm{TiO}_{2}$ Nanotube Array Electrodes for Efficient Biosensor Applications. J. Mater. Chem. 2009, 19, 948-953.

(46) Varghese, O. K.; Gong, D.; Paulose, M.; Grimes, C. A.; Dickey, E. C. Crystallization and High-Temperature Structural Stability of Titanium Oxide Nanotube Arrays. J. Mater. Res. 2003, $18,156-165$.

(47) Zhu, K.; Neale, N. R.; Halverson, A. F.; Kim, J. Y.; Frank, A. J. Effects of Annealing Temperature on the Charge-Collection and Light-Harvesting Properties of $\mathrm{TiO}_{2} \mathrm{Nanotube-Based}$ Dye-Sensitized Solar Cells. J. Phys. Chem. C 2010, 114, 13433-13441.

(48) $\mathrm{Yu}, \mathrm{J}$; Wang, B. Effect of Calcination Temperature on Morphology and Photoelectrochemical Properties of Anodized Titanium Dioxide Nanotube Arrays. Appl. Catal. B-Environ. 2010, 94, 295-302.

(49) So, S.; Hwang, I.; Riboni, F.; Yoo, J.; Schmuki, P. Robust Free Standing Flow-Through $\mathrm{TiO}_{2}$ Nanotube Membranes of Pure Anatase. Electrochemistry Comm. 2016, 71, 73-78.

(50) Baggetto, L.; Charvillat, C.; Thebault, Y.; Esvan. J.; Lafont, M.-C.; Scheid, E.; Veith, G. M.; Vahlas, C. Amorphous Alumina Thin Films Deposited on Titanium: Interfacial Chemistry and Thermal Oxidation Barrier Properties. Phys. Status Solidi A 2016, 213, 470-480.

(51) Albu, S. P.; Ghicov, A.; Macak, J. M.; Hahn, R.; Schmuki. P. Self-Organized, FreeStanding $\mathrm{TiO}_{2}$ Nanotube Membrane for Flow-through Photocatalytic Applications. Nano Lett. 2007, 7, 1286-1289. 
(52) Crawford, G.A.; Chawla, N.; Das, K.; Bose, S.; Bandyopadhyay, A. Microstructure and Deformation Behavior of Biocompatible $\mathrm{TiO}_{2}$ Nanotubes on Titanium Substrate. Acta Biomaterialia 2007, 3, 359-367.

(53) Crawford, G. A.; Chawla, N.; Houston, J. E. Nanomechanics of Biocompatible $\mathrm{TiO}_{2}$ Nanotubes by Interfacial Force Microscopy (IFM). J. Mech. Behav. Biomed. Mater. 2009, 2, 580-587.

(54) Schmidt-Stein, F.; Thiemann, S.; Berger, S.; Hahn, R.; Schmuki, P. Mechanical Properties of Anatase and Semi-Metallic $\mathrm{TiO}_{2}$ Nanotubes. Acta Materialia 2010, 58, 6317-6323.

(55) Hirakata, H.; Ito, H.; Yonezu, A.; Tsuchiya, H.; Fujimoto, S.; Minoshima, K. Strength of Self-Organized $\mathrm{TiO}_{2}$ Nanotube Arrays. Acta Materiala 2010, 5, 4956-4967.

(56) Chang, W.-Y.; Fang, T.-H.; Chiu, Z.-W.; Hsiao, Y.-J.; Ji, L.-W. Nanomechanical Properties of Array $\mathrm{TiO}_{2}$ Nanotubes. Micropor. Mesopor. Mat. 2011, 145, 87-92.

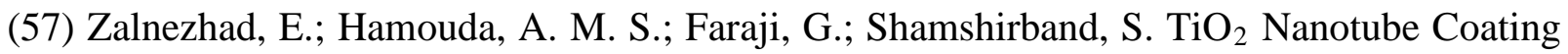
on Stainless Steel 304 for Biomedical Applications. Ceramic International 2015, 41, 2785-2793.

(58) Xu, Y. N.; Liu, M.N.; Wang, M. C.; Oloyede, A.; Bell, J. M.; Yan, C. Nanoindentation Study of the Mechanical Behavior of $\mathrm{TiO}_{2}$ Nanotube Arrays. J. Appl. Phys. 2015, 118, 145301.

(59) Munirathinam, B.; Neelakantan, L. Role of Crystallinity on the Nanomechanical and Electrochemical Properties of $\mathrm{TiO}_{2}$ Nanotubes. J. Electroanal. Chem. 2016, 770, 73-83.

(60) Correa, G. C.; Bao, B.; Strandwitz, N. C. Chemical Stability of Titania and Alumina Thin Films Formed by Atomic Layer Deposition. ACS Appl. Mater. Interfaces 2015, 7 (27), 1481614821. 
(61) Lefèvre, G.; Duc, M.; Lepeut, P.; Caplain, R.; Fédoroff, M. Hydration of $\gamma$-Alumina in Water and Its Effects on Surface Reactivity. Langmuir 2002, 18 (20), 7530-7537.

(62) Ganapathy, V.; Karunagaran, B.; Rhee, S. W. Improved Performance of Dye-Sensitized Solar Cells with $\mathrm{TiO}_{2}$ /Alumina Core-Shell Formation Using Atomic Layer Deposition. J. Power Sources 2010, 195, 5138-5143.

Table of contents

High-aspect ratio anodic $\mathrm{TiO}_{2}$ nanotube layers were coated by additional $\mathrm{Al}_{2} \mathrm{O}_{3}$ layers using atomic layer deposition, resulting in very remarkable enhanced thermal, chemical and mechanical stability. This enables to spread the application of anodic $\mathrm{TiO}_{2}$ nanotube layers to higher temperatures than before $\left(870^{\circ} \mathrm{C}\right)$ and extremely acidic conditions, not feasible before.

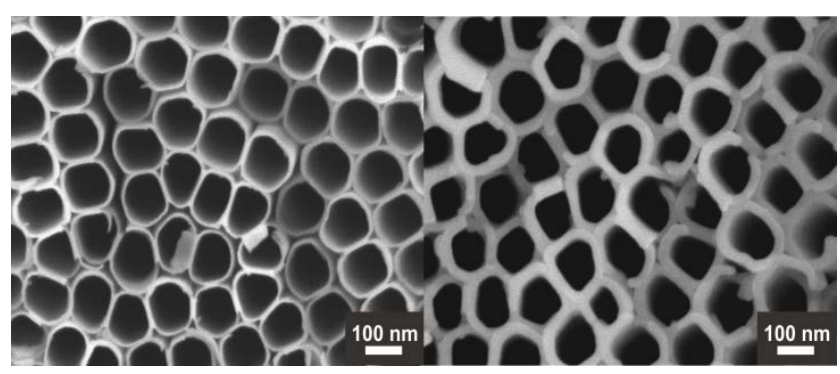

